\title{
Illicit crops in Brazil. The rural workers between income and the exploitation of drug trafficking
}

\author{
Paulo Cesar Pontes Fraga \\ Federal University of Juiz de Fora-MG, Social Science Department, Pos-graduate Program of Social Science, Juiz de For a, Brazil
}

\author{
Email address \\ paulo.fraga@ufjf.edu.br
}

To cite thisarticle:

Paulo Cesar Pontes Fraga. Illicit Crops in Brazil. The Rural Workers between Income and the Exploitation of Drug Trafficking. Humanities and Social Sciences. Vol. 2, No. 6, 2014, pp. 211-222. doi: 10.11648/j.hss.20140206.20

\begin{abstract}
The aim of this article is to analyze the cultivation of cannabis in the Vale do Sao Francisco, in north-eastern Brazil, the largest producer in the country. It also seeks to identify the main actors involved in cultivation, their interrelations, and to discuss how cannabis cultivation was established as an alternative to a much needed agricultural policy in the region and hierarchical and authoritarian relations in the local bossism. The cultivation of cannabis is placed in a context in which illicit growth is constituted and institutionalized as a complementary economy to licit cultivation.
\end{abstract}

Keywords: Illicit Cannabis Cultivation, Politic of Drugs, Rural Workers and Northeast of Brazil

\section{Introduction}

Studies that provide a better understanding of the dynamics of illicit cannabis cultivation are scarce in sociological literature. There is a significant gap that hinders a more specific understanding of the cultivation of this plant and the relations between the actors involved in its cultivation. Despite sociological research into the use and trade of marihuana and hashish (Becker, 1963; Velho, 1998), all of which are plant by-products, there are no classic and established studies on agricultural activity.

The number of families and farm workers involved in the cultivation of cannabis around the world is significant (Fraga, 2010). In spite of an important growth in hydroponic cultivation in recent years, and of other non-traditional forms of cultivating the plant mostly in Canada, USA and England, traditional and conventional cultivation of 1cannabis, which is extensively grown on surfaces, is the main productive modality of the plant. This modality also requires a considerable work force and is widespread in countries that export or consume its products, where farmers depend on these plantations to assure their livelihood. There are evidently important distinctions regarding engendered social and financial relations due to production methods. Extensive

1 Cannabis is globally produced in almost all latitudes, although most plantations are located in Africa. It is the most consumed and illicitly cultivated plant in the world plantations generally involve family production and establish specific roles for the respective actors responsible for the productive process, thus creating institutionalism, in addition to the need for fewer resources that enable poorer farm workers to be included in the productive process.

In recent years, research on cannabis cultivation in African countries has widely contributed to an understanding of the dynamics, constructed social relations and the importance of the role cultivation has on family finance and the development of regions and populations. Contrary to coca and poppy cultivation, two other important illicit cultivations, cannabis plantations are geographically dispersed at a much quicker rate and can be found in all continents. Unlike these two illicit cultivations, however, cannabis does not have such an extended black market.

\footnotetext{
2 The cultivation of poppy was legalized by the Single Convention on Narcotic Drugs of the UN and other treaties, with the supervision of each producing country. Although the coca leaf is listed as an illegal substance, its inclusion received severe criticism due to its importance to some Andean communities, leading to a negotiation of paragraph 2 of article 14 in the UM Convention against illegal trafficking of narcotics and psychotropic substances in 1988, which considers traditional and economical uses legal insofar as measures are adopted to eradicate illicit cultivation. Cannabis does not have a conventional legal usage although it is sold in coffee shops in Holland, where consumption and sales under certain conditions is permitted, and in some North American states, where it can
} 
Discussions and reflections presented herein are derived from experiences of the author in studies and research conducted in the region for the last 10 years, primarily extracted from two studies conducted in 2006 and 2010. These studies were developed using qualitative and quantitative methods that denote a rich radiography on the role of 3 cannabis plantations in local communities. The identity of the people interviewed in this study has been withheld for safety reasons, and this strategy was maintained in the writing of this article.

\section{Illicit Plantations, Economy and Actors}

Sociological and financial studies on the cultivation of cannabis have shown the close relation between licit and illicit cultivation. The role of illicit cultivation in the compensation of losses of legal cultivation, scarcity of financial resources and agricultural policies has been widely observed. According to Perez and Laniel (2004), the cultivation of 4cannabis in some African countries, such as the Republic of Cameroon, Guiney and Lesotho, compensates losses in agricultural income (decrease in the price of raw material, reduction of useable surfaces, desertification and salinization). The expansion of cannabis crops between 1980 and 1990 provided a solution for African farmers regarding the deterioration of overall agricultural activity. It represents a means of integration to new markets that emerged within the context of liberalization of State sectors, as marihuana suffers less than traditional market products. A study (COMMISSION EUROPÉENNE, 1995) reveals the comparative advantage of marihuana cultivation in relation to other crops. In 1995, one hectare of cannabis yielded 100 times more that the same number of coffee crops and 55 times that of a rice plantation in the Ivory Coast. In Gambia, the same cultivated area of cannabis is worth more than the same area planted with cassava and 10 times more than the same area planted with peanuts. Daily wages in cannabis plantation are 7.5 times higher than the wages earned at a cacao plantation and, in Cameroons, in 1997, one hectare of cannabis produced 12 times more than a hectare of apples, beans or corn.

Cannabis is present in these contexts as compensatory cultivation in regions that are strongly governed by export income cultures and areas that suffer ecological degradation and reduction of cultivable surfaces or both phenomena. The cannabis cultivation period in these locations generally varies from three to six months within a short cycle, which

be sold with a medical prescription.

3 Cannabis is globally produced in almost all latitudes, although most plantations are located in Africa. It is the most consumed and illicitly cultivated plant in the world

4Cannabis is the most commonly found illicit cultivation, mainly because it is marijuana the most commonly used drug and the adaptation of the plant, which is significant. allows quick investment and results in a more attractive market product. In the Republic of Cameroons, the cultivation of cannabis compensates the difficulties in selling traditional crops such as beans, corn and potato.

Gueye (2007) studied agriculture in the Bignona region, in Senegal, and also observed that degradation of living conditions and chronic food insecurity to which communities are submitted are decisive factors for the expansion of cannabis plantations. The short cultivation cycle of around 50 days, the reduced financial resources needed for planting and low deterioration rates that facilitate storage and commercialization conditions make this plant a genuine income alternative for local farmers.

In another study, Laniel (2001) observed that cannabis crops are traditional in South Africa, pertaining to the farming culture of many ethnic groups mainly in Lesotho. Resumption of a modern trade of this plant, however, led to the involvement of new actors in the productive cycle. Extensive use of land and grain cultivation for the foreign market in the $19^{\text {th }}$ and $20^{\text {th }}$ centuries resulted in depletion of land in the mountain regions, transforming the cannabis cultivation into a production alternative.

The cultivation of cannabis is dissipated all over the country including around the capital city, Maseru, and the main plantation areas in the central and western regions of the country. According to the author, plantations in the east were also observed. Cannabis is a traditional plant and its presence in Lesotho dates back to 1550 , according to public records. Its medicinal and recreational use is still quite widespread, which makes it an important agricultural product that fills a financial gap left by other cultures that transformed the mountain region into extensive areas of erosive land.

In other locations cannabis has been responsible for the improvement of important social indicators such as the Human Development Index (HDI). Studies conducted by Alhama, Mesa and Dominguez (2006) and Alhama, Martos, Mesiss a and Merkouzi (2005) report an experience in Zoumi, Rif, a mountain region in the north of Morocco, in which cultivation of cannabis in the last years has become the main source of income for the local community. The conditions of illegality suffered by the community and the precariousness of the region, with scarce infrastructure, secular conditions of poverty and income obtainment difficulties, linked to the traditional cultivation of cannabis, present important paradoxes.

In the midst of a desired isolation and illegality, improvements to quality of life conceal disputes regarding sustainability of the community itself that benefits from the positive increase of its indicators. The community manifests a desire to maintain the situation at the current level, despite pressure of the Moroccan government and foreign institutions to adopt other income generation methods.

According to research, the paradox is in the desire to maintain the precarious infrastructure, as they present an important element for cannabis culture in the region, obstructing police operations and creating favourable factors 
for development in the region. The community prefers not to pursue improvements of infrastructure, such as building roads for production distribution or better communication methods, as this would impair continuity of cannabis cultivation. This means that an improvement of the Local Development Index (LDI) could indirectly lower the HDI. A study of Alhama, Mesa and Dominguez (2006) showed that around $80 \%$ of interviewed farmers justified cannabis cultivation as an important tool against poverty as development of this activity in the past years has resulted in a substantial evolution of social and financial conditions.

Labrousse and Romero (2002) evaluated the cultivation of cannabis as being responsible for the fixation of large population clusters in Rif, and for reverting migratory processes to other Moroccan regions and other countries. An estimated 200,000 families, around one million people, survive from cannabis cultivation in the region. The authors, however, detected conflicts caused by the expansion of plantation areas. Disputes have been observed in addition to intensification of family conflicts resulting from land control issues. Since the 1980s, other production increase derivations were incentives for the migration of farmers to the hashish trade, making them abandon traditional crops and tribal leadership to a new emerging class of traffickers.

Cannabis cultivation in Paraguay became more intense, especially after 1985 (Benito, 2009), targeted at an illicit market, and therefore non-traditional, although the presence of the herb had already been detected in various national regions in the 1970s. Growth of plantations in the 1990s and 2000s implied leadership of the country in the production of cannabis in relation to other South American countries.

Cultivation is present in the Eastern Region and related illicit activities are limited to cannabis plantation and processing. According to data of the National Anti-Drugs Secretariat of Paraguay (SENAD), the main plantation areas are in the Department of Amabay, San Pedro and Canendiyu. Due to the expansion of cannabis culture, however, smaller plantations are also currently found in the departments of Concepcion, Caaguazu, Caazapa, Alto Parana and, incipiently, in Itapua.

The Department of Amambay borders the Brazilian state of MatoGrosso do Sul and is considered the largest producer of cannabis of Paraguay, with notable concentrations of plantations in the city of Capitan Bado.

Paraguay does not have a domestic market for the cannabis that is produced internally, so most of the production is targeted at neighbouring countries with larger consumer markets, such as Argentina, Chile and, mainly, Brazil. The characteristic of production aimed at the external market encouraged large farmers in bordering regions to invest in illicit plantation to increase their income and obtain better results. Land located in the borders has also become very attractive to Brazilian traffickers, leading them to acquire lots of land for plantation and export of cannabis to supply the Brazilian market (SENAD, 2010).

A large portion of farmers involved in cannabis cultivation adhered to the culture due to a lack of governmental incentives for the agriculture of traditional products, such as corn and cotton. Furthermore, they receive seeds from the supplier, money in advance for their crops and are in charge of the entire product marketing process.

According to Gallardo (2006), the Paraguayan farmer is poor, generally indigenous, and has a very tough work day. In most cases, plantation is carried out in areas where the property is unclaimed. After selection, land is burned for better usability for sowing, followed by the start of plantation. A producer is estimated to receive between 3-5 dollars per kilogram of marihuana, which is considered low although work is better remunerated than work in traditional agricultural products.

Another Latin American country that has important cannabis production is Mexico. In spite of its important consumer market, most produce is targeted at the external market, namely the United States of America. Social expenditure for plantation eradication operations active since the 1970 is high. The battle that has taken place in main cultivation states in the North-east region of the country (Sinaloa, Chichaua and Durango) for the last decades has caused the weight of military action to incisively fall on the small-scale farmers involved in plantations or not, who endure torture, imprisonment or expulsion from their native regions.

The main drug lords, however, are not arrested and when they are, they are soon replaced by other traffickers. Those who have close connections with members of the local government, later settle in other regions of the country, such as Jalisco, with more expansive transactions that are subdivided into other more solid branches (ASTORGA, 2001). Instead of financially weakening the groups involved in this business, the strategy eventually strengthens them as it only causes territorial displacement of groups, enabling them to settle in an important industrial nucleusthat provides a platform for business internationalization (ASTORGA, 2000).

According to a report of the International Narcotics Control Board (INCB) (2011), the illicit production of cannabis smuggled from Mexico to the USA is the most important source of income of Mexican drug cartels, amounting to US\$ 8.5 billion or $61 \%$ of their income. In spite of strong repression of drug cartels in the last years by the Federal Government of Mexico (INCB, 2011) leading to the incarceration of around 35,000 individuals and 28,000 homicides, since 2006, cannabis cultivation has increased $35 \%$ from 2008 to 2009, especially in the Oeste de Sierra Madre area. In 2009, production reached its peak in relation to the last 20 years and although it is a cheaper product than other drugs such as cocaine, heroin and crystal methamphetamine, high production ensures feasibility due to the production and marketing bases on both sides of the USAMexico borders.

In the valleys and mountains of the southern region of the State of Chihuaua, which is between the states of Sinaloa and Durango, a third of the farming population is estimated to survive from gains of cannabis plantation (Johnson, 2010). 
Most of these farmers have fire arms due to the violence that is present in the location. Low production costs attract these farmers who, similarly to farmers of Paraguay and the abovementioned African countries, find it extremely difficult to maintain a dignified livelihood from the cultivation of traditional crops. Production costs basically consist of bags of seeds, small quantities of fertilizers and the use of a primitive irrigation system that comprises low-cost rubber hoses. Blossoming of the herb is observed only three to five months after plantation.

An essential element to be observed is the type of criminality that cultivation of these plants encompasses. The illegality of cultivation itself varies according to the social organization in which they are developed, but most of the people involved are small-scale farmers that are not associated to violent criminal activity. The productive nature requires immersion in the activity, limiting participation of these farmers to this stage of the production chain of certain psychoactive substances. Cultivation of cannabis enables greater gains when compared with traditional products. The institutionalization of actions and tasks related to the cannabis culture economy, however, may cause conflicts among the actors that reside in the chains of its production.

\section{The Vale do Sao Francisco Region: Inequalities, Social Struggles and State Intervention}

Brazil is an important consumer of cannabis and imports around $60 \%$ of its product demand. Production of cannabis on Brazilian soil is significant, in quantitative terms, but insufficient to supply the national demand (Gallardo, 2006). National production provides the internal market, comprising specificities that production reproduces inequalities found in traditional farming, income concentration, linked to strong hierarchies.

Contrary to the above mentioned African countries and South American countries, such as Paraguay and Mexico, Brazilian production does not target external markets and focuses exclusively on the domestic market. Provision often excludes main consumer centres such as Sao Paulo and Rio de Janeiro, which obtain their supply of cannabis from neighbouring Paraguay. The largest concentration of plantations in the country is in the poorest region of Brazil, the Northeast, with intense dry seasons where traditional farm production faces serious problems of cultivation, commercialization and transportation to the consumer market. 5

The middle and lower middle Sao Francisco regions are among the poorest in Brazil, where, due to long droughts, small-scale farmers find difficulties in cultivating traditional

5 Around 3 million people reportedly died as a consequence of too many dry seasons in the region between 1825 and 1983 (Villa, 2001). farming products such as cotton and onion, and family farming survives with immense difficulties. This region is also the largest producer of cannabis in Brazil, harbouring constantly expanding production in the past years.

Historically, the town called Vale do Sao Francisco developed slowly thanks to extensive cattle breeding, which is essential for sugar-cane cultivation, a basic genre in the global market mainly after the $16^{\text {th }}$ century (CameloFilho, 2005). Sugar was an important agricultural product in colonial Brazil and was one of the first monoculture activities that characterized Brazilian agriculture for centuries.

The Sao Francisco River played an essential role in the development of this town and the control of interior regions, as vessels sailed down its waters enabling trade between the semiarid regions and coastal regions of Brazil, in addition to narrowing the distance between the north-eastern sertao (backcountry) and the richer South-eastern region. In the $19^{\text {th }}$ century, Burton (1977), a pioneering researcher, conducted studies on the river and participated in exploration expeditions. He analysed its role as a communications and trade channel between economically developed regions and the poorer regions. According to Burton, the river prevented product and food scarcity, assuring transportation of surpluses from productive and central regions, namely during long characteristically dry weather periods that affect the fragile productive farming structure.

Burton (1977) was also a pioneer in identifying adequate conditions along the margins of the Sao Francisco River for the cultivation of cannabis. The British explorer, however, referred to the possibility of crops for fabric production from hemp fibres, which was valued by the market and widely adopted at the time.

In spite of the potentialities and numerous state investment proposals, Vale do Sao Francisco has a low human development rate and chronic financial indicators (CameloFilho, 2005). At the start of the $20^{\text {th }}$ century, the region suffered various social conflicts. Land owners disputed with indigenous peoples, quilombolas (communities of former slaves) and small-scale farmers with private militias, originating in family quarrels and death squads that are still present in some cities. Disputes were and are responsible for an increase in violent rates in the region. These conflicts conciliate the genealogy of the so-called coroneis(landlords), holders of local political and financial powers, with the capacity for bossism and determination of laws and order in their cities and localities (Fraga, 2003).

The struggle between families and relations of authority that allow family groups to remain in power and the control of public governmental and judicial institutions implemented a legacy of bossism that subjugates most of the population of the north-eastern sertao to laws that these powerful groups have created and to the asymmetric relations that still characterise the region.

Feuds between families that struggle for power, reflected in the agrarian conflict of land possession and local political disputes, migrated to cities like Belem do Sao Francisco and Floresta, in Lower-middle Sao Francisco, in order to control 
the cannabis plantation business. These groups act in regional cities to control the selling and purchasing of seeds and recruit rural workers to participate as actors of the cultivation network.

Significant changes for the promotion of governmental intervention only occurred in the post-war era through northsouth integration actions and programmes that helped develop these waters as a tool (Ribeiro, 2006). Consequently, two actions were chartered by governments: the implementation of hydroelectric plants for power generation in specific river points and irrigated agriculture in the agribusiness modality.

Hydroelectric plants caused an important migration of people from the region. The building of 3 dams, Xingo, Paulo Afonso and Itaparica, submerged cities for the creation of lakes, which led to this significant population shift. These actions also resulted in the emergence of rights movements for farm workers, who demanded resettling and were unhappy with government cash indemnity and the lack of public policies for the affected population.

In 1986, after a two-year struggle, 6000 rural families were allowed to resettle on irrigated land. In spite of the struggle and conquests during the last decades, successful programmes to finance family farming have not been implemented. These programmes are essential for the fixation of people in the region and assured continuance of traditional crops such as onion and cotton.

In 1974, the Federal Government founded a specific stateowned company to promote and develop regional programmes called the Companhia de Desenvolvimento do Vale do Sao Francisco (CODEVASF). This proved to be relevant for greater regional focus, promoting a concentration of investments in agribusiness areas and large projects, but irrelevant for the poorer population. An increase in investments in fruit production in semiarid areas with irrigated land rendered positive results, permanently inserting the region in the national and international tropical fruits market (Silva, 2001). These project actions, however, promoted income-concentrated development. Initially planned projects that granted rural workers of the Vale do Sao Francisco access to land, such as the recently created Rural Gentrification Programme ( ${ }^{6}$ Programa de Valorização Rural) (PRONAF), were insufficient to improve technical difficulties and support for small properties (Belik, 2000). As stated by Toneau, Aquino and Teixeira (2005), the operational logic of the programme excludes poorer farming families, namely those located in the north-eastern region of Brazil. These authors reported that $78 \%$ of programme resources are applied to the richer southern and south-eastern regions of the country. The Northeast, comprising more than $50 \%$ of potential grantees, received only $14 \%$ of applied resources, resulting in a widening of the social exclusion and

6 The Commissions of Vale do Sao Francisco (CDVS) was created in the 50s, prior to the CODEVASF, and the Superintendência do Vale do Sao Francisco (SUVALE), an institution of the military regime, replaced SUVALE in 1972. regional inequality gap.

The challenge faced by Federal Government planning authorities is precisely to implement financial and developmental policies that include the majority of rural workers in the Vale do Sao Francisco, which has low social and human development indicators, allowing the extension of irrigated agriculture with technology present in local agribusiness to the small-scale farmer. Local political interests and pressure from agribusiness groups, however, force the concentration of resources to other sectors of agricultural production.

\section{Cannabis Cultivation in the Region: Production forms and Involved Actors}

Significant social inequalities, a scarcity of agricultural policies for small-scale farmers, authoritarianism and violence, which are typical of a regional historically dominated by the oligarchy of landowners, and interventionist public policies that intensify income concentration and social exclusion, form the scenario for illegal cultivation of cannabis in the middle and lower middle Sao Francisco. This region is known as the Marihuana Polygon (Poligono da Maconha) due to the numerous cannabis plantations.

In addition to Burton, the presence of this plant in the region was also reported by Pierson (1972) in a study for the Brazilian government conducted in the $50 \mathrm{~s}$ on the Vale do Sao Francisco. The author describes situations in which the use of marihuana is common in certain locations, consumed in groups in a semi-ritualistic manner, and reports plantations in at least five communities located at the margins of the Sao Francisco River. Another elements noted by the American anthropologist is minimal police operations in plantations at that time. Pierson also observed marihuana trading established outside the region, in more developed national regions such as Salvador, Santos and Rio de Janeiro.

The presence of cannabis in Brazil dates back centuries. It was brought to Brazil by slaves (Carlini, 2003; Pernambucano,1937), and consumption was initially attributed to Africans that were brought to the country as slaves to work in sugar cane plantations, hence the name, "fumo de Angola" (Angola smoke), a reference to the African home country of many men and women during the slave period. In the $18^{\text {th }}$ century, the Portuguese monarchy encouraged the plantation of cannabis. In a letter addressed to the commander-in-chief and governor of the captainship of Sao Paulo, the viceroy of Portugal notified the transportation of sixteen bags of hemp seeds to the port of Santos for cultivation in Brazilian soil; an endeavour that was of interest to the Crown (CARLINE, 2003). Successful cultivation test records of this plant for textile purposes were recorded in Santa Catarina and Rio Grande do Sul during the colonial period (Santos et al., 1983). According to Carline, until the mid- $19^{\text {th }}$ century, hedonistic use of the plant was restricted to slaves and Indians, who also cultivated the plant after this 
period. Studies of the physician Jean Jacques Moreau influenced the popularity of this plant in urban areas, which was sold in the form of a cigarette and advertised for its therapeutic properties against bronchitis, asthma and insomnia.

The prohibition to cultivate, harvest and consume this plant dates back to 1938. After this date, the planting of marihuana was prohibited although there was no organized strategy of the government or public safety authorities to eradicate plantation. The plantation restriction lasted throughout the $50 \mathrm{~s}, 60 \mathrm{~s}$ and $70 \mathrm{~s}$ in a somewhat systematic and sporadic manner in regions where plantations were discovered, but there were no articulate actions or periodical operations to repress cultivation. Cannabis plantations in various Brazilian regions, namely Vale do Sao Francisco, grew without much restraint. Law enforcement, however, was only intensified and decisively carried out after the mid 80 s, linked to the growth in marihuana consumption and the consequent market expansion.

According to a study (Fraga, 2010; Fraga, 2003), rural workers involved or not in cannabis cultivation and other local actors in Vale do Sao Francisco stated that traditional use of marihuana had not been currently recorded in the region. They claimed that there have always been plantations but that activity is focused on sales although they were unable to determine the duration of this activity.

Cannabis cultivation intensified in the $80 \mathrm{~s}$ when the increase in production targeted a higher demand in the domestic market. According to statements of regional farmers who were hired as employees to work on the land located on the islands of the Sao Francisco river in this same period, the start of fruit farming activities in the 1970s was one of the factors that enabled activity expansion, especially distribution, as in that period, the herb was transported together with the fruit.

In the 70s, production of the Sao Francisco River consisted of rice and onion, but with the arrival of the mango and other tropical fruit, and the evident potential, marihuana was also introduced. Marihuana was inserted in fruit farming. Improvements of transportation, flowing to large cities also made it easier. Mango was transported, and as it had such a strong smell, marihuana could be transported with the fruit. The smell of mangoes smothered the smell of marihuana. Production was also easier because a lot of the land in the islands of the Sao Francisco River only had one owner, and he would put about 20 goats to work that only left the land after harvesting to cover up the activities. The problem is that things did not remain that way, with the land owners. The workers that felt oppressed soon realized that they could also make money. In the 1980s, this activity grew drastically, it exploded. The municipality of Oroco is a good example. At one point everyone was planting: property owners, politicians ...everyone planted there. The municipality didn't have anything, but everyone had a car, a motorbike... And transportation was possible thanks to fruit farming 7

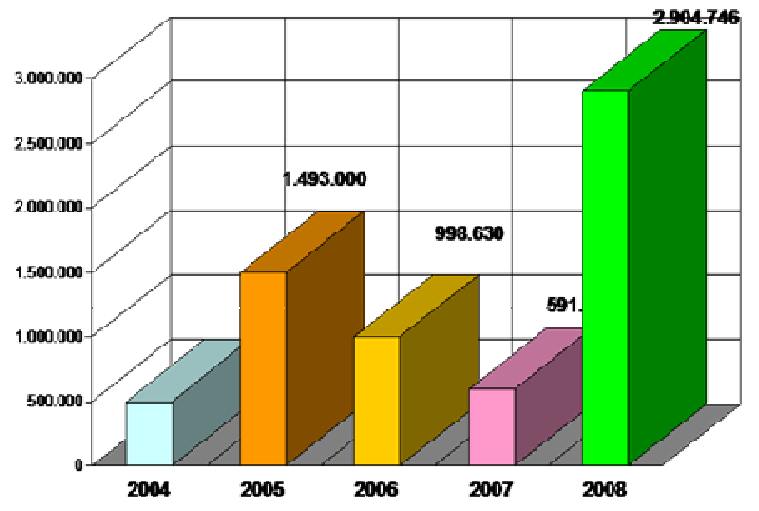

Source: Federal Police

Graph I. Number of cannabis plants eradicated in Brazil - 2004 to 2008

There is no safe estimate of domestic cannabis production in Brazil, but actions are concentrated in the Northeast, namely the lower and lower middle Sao Francisco, where a special Federal Police unit was created to conduct operations involving plantation areas. There has been a decrease of marihuana plant eradication, which does not imply a decrease in plantation areas or cannabis production. Contingents, time and intensity of eradication operations have a direct influence on apprehension and do not imply lesser plantations. In the last years, there has been a reduction of eradication actions and manpower for operations, which was very intense in former years.

Almost all eradicated plantations (98\%) shown in Graph II are in the Northeast of Brazil, with emphasis on the sertao of Bahia and Pernambuco and the State of Maranhao. Approximately 40 thousand workers are estimated to be directly and indirectly involved in cannabis plantation, while the marihuana economy reportedly moves around BRL100 million (approximately $\$ 52$ million) annually in the Marihuana Polygon (Iulianelli et al., 2005).

Graph II. Drug seizure and eradication of crops per region-Brazil-2008

\begin{tabular}{llll}
\hline REGION & $\begin{array}{l}\text { COCAINE } \\
(\mathbf{k g})\end{array}$ & $\begin{array}{l}\text { MARIHUANA } \\
(\mathbf{k g})\end{array}$ & $\begin{array}{l}\text { MARIHUANA } \\
\text { PLANTS (unit) }\end{array}$ \\
NORTH & 678.00 & - & 35,000 \\
NORTHEAST & - & - & $1,952,000$ \\
CENTRE-WEST & $1,221.83$ & $11,603.00$ & 0 \\
SOUTHEAST & $1,230.30$ & $6,897.35$ & 0 \\
SOUTH & 627.00 & $7,762.00$ & 0 \\
\hline
\end{tabular}

Source: Federal Police

As a result of increased prohibition, plantations that were formerly visible from the roadways in the 80 s are currently located in the mid caatinga, a scrubland in the semiarid areas of Brazil with difficult access, or fluvial islands of the Sao 
Francisco River. Systematic prohibition has led to an increase in plantations in the region, resulting in an expansion of neighbouring and surrounding areas which were thus far free of plantations. The phenomenon is similar to observations of Meza (2006) on the coca plantations in Columbia, where intensified restrictions, namely after implementation of Plan Columbia, led to relocation of illegal plantations to formerly cannabis-free locations. Mere prohibition, however, unaccompanied by other more structural measures, is ineffective for eradication and only causes relocation of plantations.

Another consequence of systematic prohibition in the last decades was increased organization of cannabis farmers in order to avoid arrest by the Federal Police. In the past years, the Federal Police has intensified enforcement actions and implemented a special unit in Salgueiro, an important regional municipality, to help prevent the transportation of marihuana across federal and state roads that interconnect main north-eastern cities. Although operations are planned in this unit, authorities in Brasilia hope to use the Salgueiro unit to direct anti-plantation enforcement actions. The police acknowledge that current actions are limited to mere prohibition and destruction of plantations. The number of individuals arrested in each operation has decreased in the last years, mainly due to greater organization of farmers in relation to eradication actions and, secondly, because the police strategy, which includes imprisonment despite incarcerating players of little relevance in the local financing, production, sales and product distribution scheme, aims at creating financial losses that cause a collapse in financing schemes.

According to the police, farmers are already aware of the arrival of police helicopters in Petrolina, leading to few arrests and the abandonment of entire properties, tools and other equipment used for cannabis production. The regional rural area is quite inhospitable as plantations are located in areas of difficult access due to thorny vegetation. Those who are accustomed to entering this type of vegetation find it easier to escape the police siege. The areas of the Brazilian semi-arid possess such characteristics of low rainfall and the difficulty of planting.

We know there are informants in the airport of Petrolina because when we arrived, these individuals told the growers and when we got there, when we found the location, we only arrested small-scale farmers. Most of them run and leave their equipment behind in the sites. Another problem is the difficulty of walking through the vegetation of the caatinga(typical vegetation of northeastern Brazil consisting of xeric shrubland and thorn forests). As growers are local, it is easier for them to enter the vegetation. (Federal Police Officer, 32 years old)

Another difficulty reported by the Police is the speed in which growers reorganize themselves to return to the plantation after eradication operations.

We are on an impossible mission. We conduct the operations, remove the plants and during police inquiries, when we return to some locations where we conducted eradication work, we find new plantations. We often arrest small farmers, those who are exploited by drug trafficking, but despite all the intelligence, we have problems arresting those who finance the plantation because they are backed by powerful people. ( participant 1 , police)

Critics of forced eradication highlight three negative aspects of these strategies: 1) eradication reportedly leads to adaptations that minimize the impact, namely relocation of new plantations in unexplored areas (Farrel,1998); 2) an increase in internal conflicts similar to those reported in Bolivia at the start of this century (Reed, 2003) and; 3) serious humanitarian consequences of relocating large population clusters in some areas of forced eradication, that are similar to events in Burma, in 2003, when around one third of the population, an estimated 60,000 people, left their region to seek other survival methods (James, 2005).

Additionally, systematic repression of cannabis cultivation leads to changes in farming strategies. As the caatinga is an environmentally protected area, lacking regular and effective policing actions of surveillance and inspection, to farm in these glebes is not considered a risky activity. Another resource is to plant in the land of others, where the landowner has no plantations or does not care for the land. This strategy is used by farmers to avoid being caught in the act while committing a crime and land expropriation for land reform purposes, a resource foreseen in Brazilian legislation in case of cannabis crops on lands cultivated by the owner.

In some cases, organized and sometimes criminal groups assure continuity of cultivation by forcing small-scale farmers off their lands by means of violence and threats in a process that reproduces actions related to the Brazilian land ownership structure with elevated property concentration and expulsion of small-parcel land owners by land-grabbers and estate owners.

Rural estate owners are not common in the specific case of marihuana plantations due to the illicit nature of the activity and the inconvenience of extending plantations across very large areas that enable discovery and consequent penalties. Land-based conflict and violence, however, is still present. It would not be safe to say that recruitment of rural workers is necessarily violent or widespread. Cases of expulsion of owners from their land are not characteristic of this activity and are quite rare. Adherence to cultivation can be a long process that involves elements such as knowledge of workers that plant, generally close relatives or people that consider cultivation of this plant a beneficial trade-off when compared to other activities. A good example is the case of Sebastiao, a young man who initiated cannabis farming activities at an early age mostly because his friends were already involved and he knew some people that earned higher daily wages cultivating marihuana than other products. He claims that in his city, Oroco, many farmers are involved in cultivation and earn between two and three thousand Brazilian reais per harvest, corresponding to a three to five-month period.

During the cultivation period, farmers do not generally abandon the location to prevent theft of crops. Consequently, camping sites are erected where people take turns to watch 
the area. Safeguarding the plantation is focused more on theft-prevention than protection against police operations. Shots are seldom fired when the police discover a plantation as farmers prefer to flee and abandon the crops. Furthermore, cannabis does not require much work as cultivation is relatively simple, restricted to pruning and watering.

Interviewer: What is the work like?

Farmer: Just watering, pruning and composting...

Interviewer: Let's start at the beginning. You get there and want to plant. You've bought the seeds...

Farmer: You sow and a month later you change location, after 25 days. After changing location, after a month, you prune. A month later you prune again. Some people prune a third time. But some people only prune after the fifth.

Interviewer: So you have to be there all the time.

Farmer: Yeah...

Interviewer: Do you have to set up camp? Stay permanently?

Farmer: We put up a tent with tarp or straw. Sometimes we even use sticks or branches from the forest.

Interviewer: Where do you eat?

Farmer: We eat there, when we planted. (Participant 2, farmer)

In some cases cultivation is passed down from generations and inserted in the family farming method. Initiation can also be rooted in family life, where the father is a cannabis farmer who takes his children to the plantation area. Moreover, initiation in cannabis farming has been reportedly observed in adolescence, although younger farmers have also been observed. The attitude of parents is essential to the initiation process, whether in the form of direct stimulus or negligence in relation to the daily lives of their children. In some cases, initiation can begin at the ages of 9 or 10 , with or without the company of parents. This is the case of Sérgio, a young 18year old male who was interviewed by the author of this article (Iulianeli et al. 2005), and who started planting cannabis at the age of 12 .

Interviewee: Oh, the right age is about 15 or less. Around 15 I expect.

Interviewer: What about the other case, the father that teaches? What's that like?

Interviewee: Lots of parents have grown up in these farms, planting... Then they just push you into it, say it's good but never really explain, encouraging their kids to plant marihuana and then it's too late.

Interviewer: You said you started at 12. Do you know of anyone that started before that? Of kids that work on farms today?

Interviewee: Oh yeah...

Interviewer: How old were they?

Interviewee: I know kids of around 10 that work on the farms, of around 9. Sometimes they don't actually work, they just accompany their dads.

Interviewer: How old are they?

Interviewee: About 9, 10...

Interviewer: Accompanying their father...

Interviewee: Sometimes they accompany their fathers.
Others go alone to make some money... (Participant 3, farmer)

In addition to farmers that plant according to the family agricultural model involving family members on land chosen by the head of family for this activity, which is generally public or does not belong to them, for the aforementioned expropriation risks, cultivation can be developed in other ways. In these cases, the farmer who financed the entire production sells to intermediaries, who pass the product to other business agents, who sell the product to the end consumer.

There are cases in which the farmer is part of the productive process as a paid employee, that is, he receives an amount in cash, generally daily wages, for specific daily chores, which he will only receive at the end of the cycle. As mentioned previously, plantation is reflected in political struggles and feuds among families.

Final reports of the Drug Trafficking CPI (Parliamentary Inquiry Commission), created by the Legislative Assembly of Pernambuco in 2000, indicate this characteristic of plantation development in the region of Vale do Sao Francisco.

Currently, there are gangs that are sometimes formed by members of the same family and that produce marihuana in the region in a notably isolated manner, which means there is no unified command responsible for the entire production of marihuana in Pernambuco; in fact, marihuana production is carried out by gangs that are heavily armed but act in isolation without a transnational agenda, without money laundering and without the use of advanced technology, fighting over every little farm with extreme violence.

Today, "family wars" function only as a backdrop to bloody disputes over marihuana farms and political control over the region as gangs struggle over every inch and rob banks, armoured cars and cargo trucks, and kill for money to finance drug trafficking and political campaigns.

Sadly, hundreds of innocent people, including members of these families that have never committed crimes, are killed due to these disputes. (LEGISLATIVE ASSEMBLY OF PERNAMBUCO, 2000, p. 84).

Many interviewees mention local family groups with powers established in important regional towns, such as Cabrobo, Floresta and Belem do Sao Francisco, as the most benefitted and supposed financers of the business, that is, those who provide the inputs for cultivation and act as partners that are responsible for selling the product.

These "bosses" or "big ones", as many workers call them, can hire in a range of ways, from payment of salaries to the sharecropper system, as discussed below. This specificity indicates an important characteristic of cannabis plantation in the region: the fact that business is developed and continues to be controlled by local criminal groups.

In the case of the sharecropper system, a farmer receives seeds and is responsible for a glebe that is provided for planting, usually with an abundant water supply. In dry regions, with scarce water supplies and without irrigation, 200-litre barrels of water are transported to the crop location. 
At the end of production, all expenses of the sharecropper and farmer are accounted for, profit is calculated generally in relation to sales price per kilogram or bag of cannabis and, finally, the profit is divided between the two business partners.

The sharecropper system is commonly adopted in regional agriculture as a productive modality involving other legally tradable agricultural items. The cannabis farm requires fewer inputs, less work and generally provides higher financial return to the farmer. Its specificity in relation to other cultures is the need of the worker to set up camp inside the land to avoid theft of other farmers or drug traffickers. Grocery shopping is generally done to maintain the group for the two or three months they will camp in the farm. This isolation means that most farmers should preferably be men, although there are women in these camps working as growers or cooks, especially in the case of family farming.

Due to the illegal nature of cannabis plantations, the risk of losses is high. If the plantation is located by the police, in addition to the possibility of prison, the farmer losses all the financial and labour investment.

Interviewer: How does the scheme of people planting for others work? Does the contractor provide the seeds?

Interviewee: He gives the seed, the land, and it has to be a place with lots of water, because it's impossible without water. And he has to do the shopping (grocery) for us to stay in the farm. Then you calculate your expenses, when you harvest, you calculate the expenses of everything you spent. Then you divide it with the owner. For example, you plant in a farm that has low expenses. The farm with the lowest expenses, I think, is the marihuana farm.

In the caatinga you have to make the farm look like caatinga. You have to cut away some bushes but not too much, so the light doesn't come in, so no one can see it from far away. You have to put some bushes around it, surround it with bushes, so no one can see. If you're lucky and God is on your side, you can make money. If not, you have losses and you can start another one if you want.

The cultivation period of cannabis varies between three to six months. This is considered a short cultivation cycle that does not require much input for production, as mentioned above. The biggest problem for a dry, semiarid region is precisely the supply of water, which is not very abundant. Consequently, in addition to planting where there is irrigation or water barrels to transport water to the crops, some plantations are located in the isles or at the margins of the Sao Francisco River. The caatinga region is largely used due to the difficulty of access and consequent protection from public safety authorities, but they are dry areas so surrounding areas with irrigation are often preferred. Farmers generally "bleed" water pipes to transfer water to cannabis crops, creating a good infrastructure for farming. The plant is cultivated using the planting hole application. Each hole measures around $1 \mathrm{~m}^{2}$ and harbours approximately six to eight cannabis plants.

Interviewer: How much do you earn per month doing this? Is it per month? Per harvest?
Interviewee: It's per harvest.

Interviewer: How long does it take?

Interviewee: five months, six months...

Interviewer: Five months to flowering. Isn't it three months?

Interviewee: Some people harvest after three months, but if you want the good the good stuff, you have to harvest in six months. It's the same thing as a company product, you have to make sure the quality is good.

Interviewer: So you harvested after six months, how much do you get?

Interviewee: It depends on the harvest. It depends on the quality of your harvest...

Interviewer: How much do you make in a good harvest? How many holes? 30?

Interviewee: Around 300 holes... I make around BRL 2,500.00, about that.

Interviewer: After six months. That's around BRL 400 per month...

Interviewee: Yeah, about that.

Interviewer: It's a much better activity. If you worked earning the usually BRL 12 you wouldn't make that in a month.

Interviewee: But it's tough to maintain. We won't steal, will we?! So you have to kind something that won't hurt anyone. We know that neighbours can call the police, they can harm us, but we don't harm anyone. We stay in our area, trying to harvest our product. I don't plant anymore, but I've planted before. I've planted but I've stopped. From my point of view that's how it is. No one harms anyone.

Interviewer: How much did you plant per harvest?

Interviewee: 250 holes.(Participant 4, farmer)

Another advantage of cannabis cultivation stated by the interviewed farmers in relation to traditional onion and pepper farming, for example, is the possibility of storing the product for sale when the price is more appealing. Farmers do not have storage conditions for traditional products so they must sell for the current market price, which is generally low. Cannabis can be stored for long periods of time that, according to data collected, varies from six to eight months. For this purpose, cannabis is generally pressed in specially constructed presses, mixed with refined sugar, packaged in Styrofoam and buried to avoid detection by law enforcement authorities. During periods in which the product has a higher price with a higher demand, such as holiday and carnival season, production can be sold at better prices.

Contrary to other countries where cannabis cultivation is widely practiced, in the lower middle Sao Francisco region cultivation does not systematically function as a financier of other traditional crops such as onion, tomato and peppers. This occurs because cannabis cultivation is an alternative to farmers facing difficulties in selling traditional products, namely in the family farming systems, that is, the largest problem of producers is the selling of their products. Consequently, many farmers resort to cannabis culture to compensate losses with traditional products that were traded 
at low prices or not traded, or even to improve family income. For small-scale farmers the cultivation of cannabis does not generally represent their sole source of income. Culture of this plant is developed in conjunction with other products to avoid dependence on this source of income and consequent loss of income during periods of intense law enforcement. 8

\section{Final Considerations}

The cultivation of cannabis in Brazil increases as marihuana is more widely consumed in the country. Contrary to some African and South American countries, production is targeted at the domestic market, but similarly to these countries, it is considered an income alternative for the farming population that suffers with climate issues and absence of systematic agricultural policies for small-scale farmers and family agriculture.

Extensive agricultural cultivation of some plants that are considered illicit has at least two specific characteristics: 1) It is a labour force activity conducted in the same way as other traditional licit crops that, despite the specificities, absorbs the work force of legal crops leading to the immediate involvement of farmers in an illicit activity with all the resulting legal implications; and 2) It is frequently used by farmers as an income alternative that eventually finances legal crops due to the lack of agricultural policies in the producing countries.

These characteristics link legal and illegal activities, as occurs with other criminal activities, especially those that require money laundering. This is not the case of cannabis cultivation, although it implies the transfer of a resource obtained from illegal activity to a legal activity for the livelihood of the grower and his family. The relevant issue here is the need for permanence of illegal cultivation. Legal crops do not allow the abandonment of illicit work as they require a constant inflow of resources.

The presence of illicit crops in a region such as lower middle Sao Francisco, in north-eastern Brazil, which is marked by poverty and land conflicts, and dominated by disputes between groups that control local bossism relations, has led to years of increased violence that is still perceptible in health and crime statistics.

In the past years, drug policies in Brazil have become less repressive to users although there is still no differentiation between the small-scale farmer involved in plantation and those who play a more important role in the illicit cultivation chain in relation to production and distribution. The absence of a law that differentiates the actors in the productive chain leads to greater criminalization of those who are at the ends of the system and the reproduction of financial inequality in

8 Brazil has a specic drug law in its penal code. Both use, as trafficking are crimes, but the use is not punishable by deprivation of liberty. Planting fits the crime of trafficking, has no specific treatment. legal punishment.

Paradoxically, however, the culture of cannabis has improved the living conditions of some farmers but has also led to relations with criminal groups, placing their lives and the lives of their families at risk. According to Toklatian (1995), in relation to fundamental aspects of the manifestation of criminal activity linked to drug production and trade: a) this activity is not restricted to a single area due to national and international connections; it is established in an area in which individual and collective social relations are facilitators of its maturity and power; b) despite the use of repressive force, this is not a sole characteristic form or mechanism as it effectively articulates and combines consensus and coercion; c) there is not rigid configuration or group behaviour pattern, but family, internal, ethnical and regional and, often times, religious bonds are essential. Finally, the author would like to clarify the importance of understanding organized crime in the juncture of which society is simultaneously victim and accomplice, as the development of criminal activities is only possible with the involvement of various actors in the developing localities.

An understanding of these dynamic processes is essential for the development of knowledge on the relations that are established between licit and illicit activities and of the sensitive line between both, which are many times combined. In the specific case of cannabis crops in the Northeast of Brazil, cultivation is presented as a fundamental activity for survival and income complement, but not as a financer of other licit crops as the essential issue is precisely linked to the trading and distribution of the traditional product in better conditions, which cannabis cultivation does not resolve.

\section{References}

[1] Alhama, José, Eulalia Molero Mesa, y José A. Rodriguez (2006), "Estructuras Sociales, Desigualdad, Medioambiente Y Desarrollo Humano: Cannabis Y Desarrollo en Marruecos", Portulária, Vol. 6, núm. 2, pp. 105-121.

[2] Alhama José ,A.V. González Martos, J. Molero Mes y, A. Merzouki (2005)," Desarrollo humano sostenible: el ejemplo de la "cultura del cannabis" en el Rif (Norte de Marruecos)", Ecossistema, núm.4, vol.3, september, pp.22-30.

[3] ASSEMBLÉIA LEGISLATIVA DE PERNAMBUCO. Relatório da CPI do Narcotráfico (2000), URL: http://www.alepe.pe.gov.br/paginas/?id=3620\&dep=\&paginap $\mathrm{ai}=3596 \&$ doc $=$ A6CA92A6AB4C348A03256A3A0052D80F

[4] Astorga, Luis (2001), 'The limits of anti-drug policy in Mexico', International Social Science Journal, vol. 53, núm,169, september, pp 427-434.

[5] Astorga, Luis (2000). "Organized-crime and the organizatation of crime”. En BAILEY, John; GODSON, Roy (Ed.) Organized cime and democratic governability.Mexicoand the US-Mexican Bordeslands. Pittsburgh. University of Pittsburgh.

[6] Becker, Howard (1963), Outsiders: Studies in the Sociology of Deviance, New York, The Free Press. 
[7] Belik, W. (2000), "PRONAF: Avaliação da Operacionalização do Programa"en Campanhola, Clayton y José G. Silva (edits) O Novo Rural Brasileiro: políticas públicas, Vol.4, Jaguariúna-SP, Embrapa, pp. 93-115.

[8] Brochu, Serge, Valérie Beauregard y Xanthia Gagné-Tardif (2009). "Cannabis cultivation in Canada", In: URL: http://www.ciroc.nl/presentaties/20071212\%20Brochu\%20can nabis.pdf, May 21st de 2009.

[9] Burton, Richard. (1977), Viagem de Canoa de Sabará ao Oceano Atlântico, São Paulo, Ed. USP.

[10] Cabieses, H. (2004), "Peru: Luchas Cocaleras y Gobernabilidad”, Drogas y Conflicto, núm. 10, april, pp.16-26.

[11] Comission Européene (1995), Afrique de l'Ouest: Étude de la production de drogues et du trafic local, en particulier, de la culture du cannabis, Paris, Ed. ComissionEuropéene.

[12] Camelo Filho, José (2005), “A dinâmica política, econômica e social do rio São Francisco e do seu vale”, Revista do Departamento de Geografia,núm.17, jan., pp.83-93.

[13] Carline, Elisaldo Araújo (2006), "A história da maconha no Brasil”, J Bras Psiquiatr, núm.55, vol.4, sep.-dec., pp. 314-317.

[14] Farrel, Grahan. (1998), "A global empirical review of drug crop eradication and United Nations crop substitution and alternative development", Journal of Drug Issue, invierno, pp.395-436.

[15] Foucault, Michel (1975), Suveiller et Punir, Paris, Ed. Gallimard.

[16] Gallardo, Jorge (2006), "Consumo, prohibición y narcotráfico" en Castilla, Alice, Cultura Cannabis, Bueno Aires, Ed.Castilla, 2006.

[17] Gettman, Jon (2006), "Marijuana Production in the UnitedStates", In:URL: http://www.drugscience.org/Archive/bcr2/bcr2_index.html, última consulta en 24 de junio de 2010.

[18] International Narcotics Control Board (2011). Report of the International Narcotics Control Board for 2010, New York, $\mathrm{INCB} / \mathrm{UN}$.

[19] Iulianelli, Jorge Atílio (2000), "O Gosto Bom do Bode: Juventude, Sindicalismo, Reasentamento e Narcotráfico no Submédio" en Motta Ribeiro, Ana Maria y Jorge Atílio Iulianelli, Narcotráfico e Violência no Campo, Rio de Janeiro, DP\&A, pp 79-92.

[20] Iulianelli, Jorge et al.. (2005), Relatório Final da Pesquisa Jovens construindo politicas públicas para a superação de situações de risco, no plantio da maconha, na região do Submédio São Francisco, Brasília, Ministério da Justiça.

[21] James, Brandi (2005), "Examining the Impact of Illicit Crop Eradication on Education in Colombia. Education", Emergencies and Post-Conflict Situations: Problems, Responses and Possibilities, Vol. 2, pp. 48-59.

[22] Johnson, Tim (2010), "Aumenta el cultivo de marijuana en México",URL:http://www.elnuevoherald.com/2010/09/04/795 586/aumenta-el-cultivo-de-marihuana.html.

[23] Labrousse, Alain and Luis Romero (2002), "Moroc: la production de cannabis dans le Rif", Bulletin mensuel du Observatoire française de drogues et de toxiconomies, núm.13, febrero, pp. 1-4.

[24] Laniel, Laurent (2001), "Drugs in Southern Africa: Business As Usual", International Social Science Journal, num. 169, vol.53,Septembre,. pp. 407-414.

[25] Laniel, Laurent(2004), "Cannabis in Lesotho", URL: http://www.indiaseminar.com/2001/504/504\%20laurent\%20laniel.htm, última consulta 8 de julio de 2010 .

[26] Mamadou, Gueye (2007), Societes rurales et developpement durable. Transformations recentes des agricultures, strategies paysannes et soutenabilite des systemes ruraux en Afrique sahelo-soudanienne : cas du departement de Bignona (Senegal meridional), Montreal, ED. Universidad de Montreal.

[27] Misse, Michel (1999), Os Malandros, Marginais e Vagabundos \& a Acumulação Social da Violência no Rio de Janeiro, Rio de Janeiro, Instituto Universitario de Pesquisa do Rio de Janeiro (IUPERJ).

[28] Motta Ribeiro, Ana Maria (2008). "O Polígono da Ma, URL: http://diplomatique.uol.com.br/artigo.php?id=213\&PHPSESS ID=7344ed5e82e51d5534f731688bd39468.

[29] Pernambucano, Jarbas (1937). "A Maconha em Pernambuco" en Freyre, Gilberto (editor.), Novos Estudos Afro-brasileiros, Rio de Janeiro, Ed. CivilizaçãoBrasileira.

[30] Pierson, Donald. (1972), O Homem no Vale do São Francisco, Rio de Janeiro, SUVALE.

[31] Pontes Fraga, Paulo Cesar (2010), “As ações de erradicação de plantios considerados ilícitos na América Latina e no Brasil”, in: Pontes Fraga, Paulo Cesar (Ed.), Crimes, Drogas e Políticas, Ilhéus, Editus,pp. 187-225.

[32] Pontes Fraga, Paulo Cesar (2007), “A geopolítica das drogas na América Latina", Revista em Pauta, núm.19, jan.-jun., pp.67-88.

[33] Pontes Fraga, Paulo Cesar (2006), "Plantios Ilícitos no Brasil: Notas Sobre a Violência e o Cultivo de Cannabis no Polígono da Maconha", Cadernos de Ciências Humanas - Especiaria, vol. 9, núm. 15 , jan.-jun. pp. 95-118..

[34] Pontes Fraga, Paulo Cesar (2003), "Da Favela ao Sertão" en Pontes Fraga, Paulo Cesar y Jorge Atílio Silva Iulianelli (eds.), Jovens em Tempo Real, DP\&A, Rio de Janeiro, pp.82-107.

[35] Pontes Fraga, Paulo Cesar (2000), “.Juventude, Narcotráfico e Violência no Brasil” en Motta Ribeiro, Ana Maria and Jorge Atílio Iulianelli (eds.), Narcotráfico e Violência no Campo, Rio de Janeiro, DP\&A, pp.81-108.

[36] Rafael, Antônio (1998), Um Abraço para todos os amigos: algumas considerações sobre o tráfico de drogas no Rio de Janeiro, Niterói, EDUFF.

[37] Reed, L. (2003) "Bolivian coca farmers defy US-bolstered ban on crops", The Boston Globe, 23 de marzo, pp. A4.

[38] Secretaria Nacional Antidroga (2010).Plan Nacional Antidrogas. Assunción, SENAD.

[39] Silva, A.P. et al. (1983), Mapeamento de áreas plantadas com "cannabis sativa" através de transparência coloridas infravermelhas (falsa-cor), in URL: http://marte.dpi.inpe.br/col/dpi.inpe.br/marte@80/2009/04.13. 12.56/doc/506-515.pdf. 
[40] SILVA, Paulo .C. (2001), Articulação do interesse público e privado no Pólo Petrolina-PE / Juazeiro-BA. Em busca de espaço no mercado globalizado de frutas frescas, CampinasSP, Universidade de Campinas.

[41] Tokatlián, Juan Gabriel. Drogas, Dilemas y Dogmas. Estados Unidos y La Narcocriminalidad Organizada en Colombia. Bogotá: TercerMundo, 1995.

[42] Tonneau , Jean-Philippe, Joacir Rufino de Aquino y Olívio Alberto Teixeira (2005 ), "Modernização da agricultura familiar e exclusão social: o dilema as políticas agrícolas", Cadernos de Ciência \& Tecnologia, Brasília, núm. 1, vol. 22, jan.-jun., pp. 67-82.

[43] UNITED NATIONS OFICE FOR DRUGS AND CRIME (UNODC) (2006), World Drugs Report 2006, Washington, UNODC.
[44] Uprimny, Rodrigo (1997). Que hacer con las Drogas? Políticas Vigentes y Alternativas Emergentes. Bogotá, Colombia, Fac.de Derecho da Universidad Nacional de Colombia, Bogotá, Facultad de Derecho.

[45] Vargas Meza, Ricardo (2006). "Drogas, conflito armado na Colômbia e segurança global", Cadernos de Ciências Humanas - Especiaria, vol. 9, núm.15, pp. 59-78.

[46] Velho, Gilberto (1998) Nobres e Anjos: um estudo de tóxicos e hierarquia, Rio de Janeiro, Ed. da FGV.

[47] Villa, Marco Antonio (2001). Vida e morte no Sertão. Histórias das secas no Nordeste nos séculos $X I X$ e XX, São Paulo, Editora Ática. 